Portland State University

PDXScholar

1976

\title{
Securing Services for the Older Population : a Training Manual for I and R Workers
}

Catherine M. Nemmert

Portland State University

Follow this and additional works at: https://pdxscholar.library.pdx.edu/open_access_etds

Part of the Social Work Commons

Let us know how access to this document benefits you.

\section{Recommended Citation}

Nemmert, Catherine M., "Securing Services for the Older Population : a Training Manual for I and R Workers" (1976). Dissertations and Theses. Paper 1883.

https://doi.org/10.15760/etd.1882

This Thesis is brought to you for free and open access. It has been accepted for inclusion in Dissertations and Theses by an authorized administrator of PDXScholar. Please contact us if we can make this document more accessible: pdxscholar@pdx.edu. 
SECURING SERVICES FOR THE OLDER POPULATION

A TRAINING MANUAL FOR I AND R WORKERS

\author{
by \\ Catherine M. Nemmert
}

A practicum submitted in partial fulfillment of the requirements for the degree of

Master of Social Work

Portland State University

1976 
APPROVED:

Gerald Frey School of Social Work 
TABLE OF CONTENTS

PAGE

PREFACE ............................ 1 . . . . . . . . CHAPTER I

INFORMATION AND REFERRAL SERVICES: AN OVERVIEW

DEFINITION . . . . . . . . . . . . . . . . . 1

RATIONALE . . . . . . . . . . . . . . . . 3

HISTORY ................... 5

FUNCTIONS . . . . . . . . . . . . . . . . 9

I AND R SERVICE FOR THE OLDER POPULATION . . . . . . . . 13

ROLE OF THE I AND R WORKER . . . . . . . . . . . . . . . 18

EXERCISES . . . . . . . . . . . . . . . 20

REFERENCES . . . . . . . . . . . . . . . 22

CHAPTER II

I AND R SERVICE PROVISION: THE PROCESS

I AND R INTERVIEWING . . . . . . . . . . . . . . . . 24

DEFINITION - INTERVIEW . . . . . . . . . . . 26

COMMUNICATION PROCESS . . . . . . . . . . . . . . 27

A HELPING RELATIONSHIP . . . . . . . . . . . . 31

CONSUMER'S RIGHTS . . . . . . . . . . . . . . . 33

WORKER'S ATTITUDES .................. 36 
PAGE

EXERCISES . . . . . . . . . . . . . . . 38

REFERENCES . . . . . . . . . . . . . . 41

CHAPTER III

I AND R SERVICE PROVISION: INTERVIEWING TECHNIQUES

INTERVIEWING SKILLS . . . . . . . . . . . . . 42

INTERVIEW SITUATION . . . . . . . . . . . . 43

BEGINNING THE INTERVIEW . . . . . . . . . . . . . . 46

INFORMATION GATHERING . . . . . . . . . . . . 50

INFORMATION GIVING AND REFERRAL . . . . . . . . . 56

TERMINATING THE INTERVIEW . . . . . . . . . . . 60

EXERCISES . . . . . . . . . . . . . . 62

REFERENCES . . . . . . . . . . . . . . . 64

APPENDIX

SUGGESTED READINGS . . . . . . . . . . . . . . 65 
PREFACE

This manual is written as a self-training guide on the elements of Information and Referral ( $I$ and $R$ ) service and on the process of providing $I$ and $R$ to the older population. The manual attempts to build a useful framework for methods of providing $I$ and $R$ service.

The manual is directed at workers who are providing $I$ and $R$ services to the elderly. It is intended to serve as an orientation guide on the basic elements of $I$ and $R$ service and as a "how to" guide for methods and techniques of service provision. The new worker should find the manual helpful as a basic training tool and the experienced worker who may wish to use the material to assess or strengthen his/her current practices.

Information and Referral services for the elderly were given high priority in the 1973 amendments to the 01der Americans Act which established a goal of providing "reasonably convenient access" to I and $R$ services for all older persons in this country. Numerous organizations are involved in providing this service, ranging from small senior centers to large public bureaucracies. With this assortment of organizations, there are differences in interpretations and methods of providing $I$ and $R$ service. $I$ and $R$ is provided over the telephone, in office settings and through outreach efforts. This manual was written in an attempt to pull together basic information on the elements and dimensions of 
I and $R$ service provision, that would be useful for all $I$ and $R$ workers securing services for the elderly.

The manual is organized in three self-contained chapters which can be used separately for the specific topic areas or together as a conprehensive training guide. Each chapter is followed by exercises which enable the worker to practice specific techniques and to apply information obtained in the text to his/her work situation. Chapter I serves as an overview and should furnish the worker with a historical perspective and an understanding of the basic elements of $I$ and $R$ service. Chapter II focuses on the process of $I$ and $R$ service provision and the interaction between the worker and the consumer. Chapter III presents techniques and guidelines for providing $I$ and $R$ service. An appendix of suggested readings is also included. The manual is most profitably used when followed by discussion with a supervisor or co-worker.

This manual is not intended as a guide to specific community resource information; it will, however, suggest ways of obtaining this information.

I wish to express my appreciation to Jerry Frey and Ada Wilson of Portland State University School of Social Work and 'Leen Pollinger of the Oregon State Program on Aging for their time in reviewing, editing, and providing support. A special thanks to Dave, Susan and Donna for their artistic help.

$$
\text { C.M.N. }
$$




\section{CHAPTER I}

INFORMATION AND REFERRAL SERVICES:

AN OVERVIEW 
DEFINITION $^{1}$

Information and Referral ( $I$ and $R$ ) is basically defined as a linking system. An $I$ and $R$ source links individuals in need of service with the appropriate services available in a community.

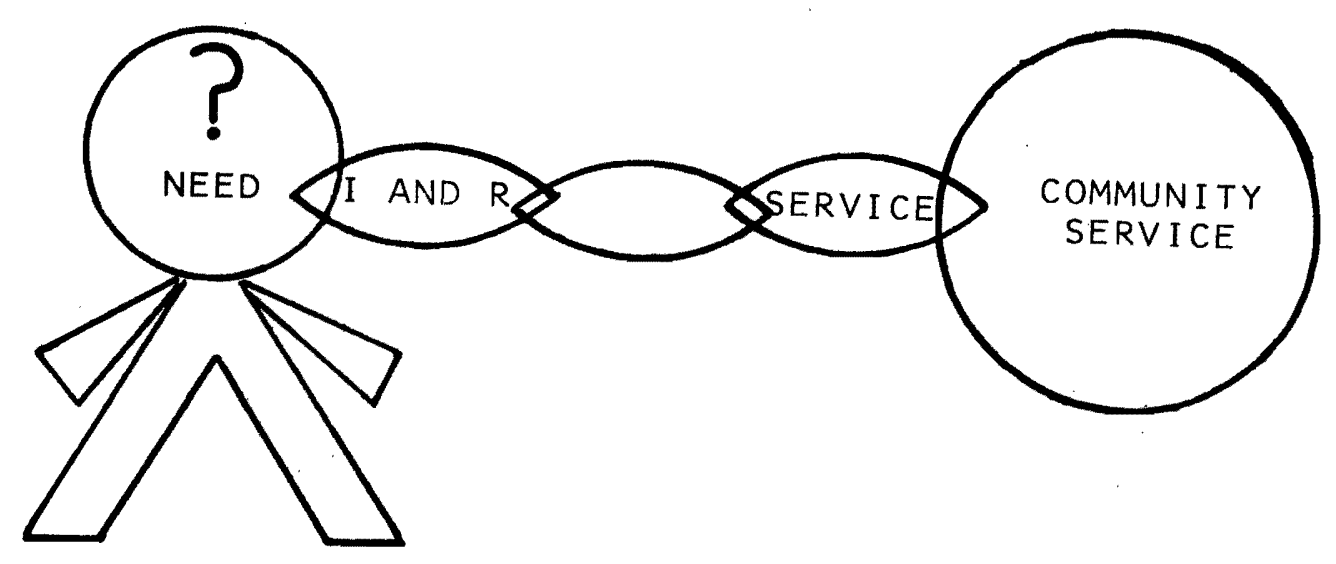

In addition, $I$ and $R$ can also be the link between individuals and community groups who plan for services.

An $I$ and $R$ service has four basic capacities:

(1) Identifying and assessing individual needs.

(2) Providing information about services.

(3) Linking individuals with services.

(4) Assisting with the community planning process.

Information and Referral can simply be defined as a service for informing individuals about community programs, in such a manner as to facilitate linkage with the programs, in order to relieve or eliminate individual problems or needs. 
$I$ and $R$ service is provided by individuals who work in either a volunteer or paid capacity for an organization which formally designates I and $R$ as a primary service. $I$ and $R$ may be the only service which an organization provides or it may be one of several primary services. An example of an organization which provides only $I$ and $R$ would be $a$ community $I$ and $R$ center. Organizations such as senior centers or community action programs may have an $I$ and $R$ unit which is one of several primary services offered by the organization. In either case, $I$ and $R$ is a separate, formally organized service.

$I$ and $R$ is also a necessary and real service. $I$ and $R$ is not merely a convenience for individuals who need help in locating services. $I$ and $R$ is a service which is necessary to insure that individuals will secure needed services. ${ }^{3}$ 


\section{RATIONALE}

$I$ and $R$ services have developed primarily in response to the increasing complexity of our community service delivery systems.* There have been increases in: (1) the number and variety of community services available, (2) the complexity of the administrative structures for delivering services, (3) the growing expectations of individuals for services. A quick glance through the telephone 1istings under U.S. or State government or Social Services, provides an excellent picture of the number and variety of services available. Since most of these programs are operated under separate administrative units, the application procedures and eligibility requirements vary. Today, even in more sparsley populated areas, where access to service is difficult, expectations are increasing that services should be available.

The growth in size and complexity of our community service delivery systems has created barriers for individuals in securing needed services. $I$ and $R$ services exist to aid individuals overcome these barriers. An underlying assumption for $I$ and $R$ services is that the service delivery system has become too complex for individuals to deal with on their own. ${ }^{4}$ The following outline lists the principle barriers to individual use of service delivery systems:

*Community service delivery systems include all federal, state, local agencies and services within a given community directed at health, social service, welfare, recreational and educationa1 needs. 
BARRIERS TO USE OF COMMUNITY SERVICES 5

1. Individual Barriers (Interna1)

a. No knowledge or insufficient knowledge about the services.

b. Inaccurate information about the services.

c. Negative attitudes about using the services or seeking help.

d. Physical or mental handicaps that prevent or limit use of services.

2. Individual Barriers (Externa1)

a. Insufficient money to purchase services.

b. Inadequate transportation to services.

c. Services not available within geographic area.

3. Barriers within service delivery systems

a. Negative attitudes of persons providing the service.

b. Problems in the method and manner of providing the service.

$I$ and $R$ services have developed to break down these barriers which prevent individuals from receiving needed services. The following section on the history of $I$ and $R$ will provide information on how this has been implemented. 


\section{$\underline{\text { HISTORY }}$}

I and $R$ services are an outgrowth of our rapidly changing urban industrial society. The increased complexity in our service delivery systems reflects the growth, complexity and impersonality of our modern way of life. The need for $I$ and $R$ did not exist when services were scarce and individuals were able to learn of those available through the communication networks of their small towns or rural areas. However, with growing concentrations of people living in urban areas, the need for services increased as well as the need for a way of informing people of the services. 6

The development of $I$ and $R$ services has been gradual. Numerous organizations have been involved in providing some form of $I$ and $R$. These services have varied in their scope and methods of service delivery. Services have been directed at different age groups, at special problem areas and at the population as a whole. There have been various interpretations in definition and methods of providing $I$ and $R$. Within the last decade, attempts have been made by a few national organizations to uniformly define and establish minimum guidelines and standards for $I$ and $R$. However, since there are few descriptive reports analyzing and comparing actual I and $R$ services, there is little basis for knowing the effects of these guidelines in practice. Although a few individual organizations have been delivering $I$ and $R$ services for many years, nationally $I$ and $R$ is in the process of emerging as a separate, clearly identifiable service. 
The following section highlights in outline form some of the major historical developments in $I$ and $R$ services.

\section{FORERUNNER OF PRESENT I AND R SERVICES}

Social Service Exchanges

These organizations began to develop in the late $1800^{\prime}$ 's in urban areas. Their primary purpose was to coordinate service agencies, to promote sharing of resources and prevent duplication of services. These exchanges 1ater developed into what became known as United Comminity Funds and Conncils of America or the more recent name, United Way of America. 7

\section{DEVELOPMENT OF I AND R SERVICES}

Information and Referral services began to emerge widely during the years of World War II. The need for $I$ and $R$ services grew as the disruptions in people's lives caused by the war increased.

United Community Funds and Councils of America

In major metropolitan areas, these organizations developed $I$ and $R$ services to assist people locate social service resources. Though a few $I$ and $R$ services developed prior to World War II, the majority developed during the war years. Today, United Way of America has over $50 \mathrm{I}$ and $\mathrm{R}$ centers in the United States. 8 In 1973, United Way of America published National Standards Information and Referral Services.

Citizens Advice Bureaux of Britain (CABx)

The development of $I$ and $R$ services in the United States has been strongly influenced by the Citizen Advice Bureaux of Britain. The Bureaux were organized during the war years to assist people with relocation and emergency problems caused by the war. ${ }^{9}$ The bureaux remained in communities following the war and today Britain has a well developed system of over 600 centers. The centers provide information, advice and referral on any subject. Although there is a national office in London, the majority of centers operates on local community support. 10

Veteran's Information Centers

These centers were set up by the U.S. Government Retraining and Rehabilitation Administration following World War II. They assisted returning veterans in the transition to civilian 1ife. Approximately 300 centers were set up, officially titled Community Advisory 
Centers. The majority of these centers was closed by 1949.11

National Easter Seal Society for Crippled Children and Adults

In 1966, the policy making body of the National Easter Seal Society passed a resolution that required all affiliates to provide a service of information, referral and follow up ( $I, R$ and $F$ ). The primary focus of the service was on linking disabled persons to available resources. Amongst the 300 affiliates in the U.S., there were varied interpretations of how this resolution was carried out. 12 In 1972, the policy making body modified the resolution, recognizing differences in community needs. $I, R$ and $F$ services are now developed and provided by the affiliates whenever feasible. In 1972, the National Easter Seal Soclety listed 175 programs of I, R and F.13

Community Action Programs (CAPs)

Local Community Action Programs, established under the Economic Opportunity Act of 1964, have sponsored I and $R$ services focusing on low income and minority individuals. 14 One of the components of CAP, Senior Opportunities and Services, has provided I and $R$ services for the elderly in many areas. In 1975, CAPs were placed under the newly named Community Services Administration of the Department of Health, Education and Welfare. Sponsorship of $I$ and $R$ services has continued.

Social Security Administration

In 1971, at the White House Conference on Aging, President Nixon directed all Social Security District offices to provide information and referral services.15 Until. June of 1974, the District Offices employed a person with the title of Information and Referral Aide. At the present time, employees of the District Offices are directed to provide community resource information. In practice, $I$ and $R$ is not a primary service provided by the offices and is done on a minimal basis.

Alliance of Information and Referral Services (AIRS)

In 1971, AIRS was formed by $I$ and $R$ providers who met yearly at the National Conference of Social Welfare. In hopes of strengthening communication between $I$ and $R$ providers, persons sponsoring $I$ and $R$ services are asked to join. ${ }^{16}$ A newsletter is published by the organization. In 1974, AIRS published The National Standards for Information and Referral Services.

Administration on Aging

The 01der Americans Act of 1965, as amended in 1973, requires that all states provide, either through their State or local Area Agencies 
on Aging, I and $R$ services reasonably accessible to all older persons in the state. 17 Every older person in this country should have access to an $I$ and $R$ service. By June 30, 1975, the Administration on Aging required minimum elements and criteria for $I$ and $R$ services to be in place. 18 This has been an extensive undertaking and has significantly boosted national awareness of $I$ and $R$ services. Most of the available literature and research on $I$ and $R$ has been funded by the Administration on Aging. 


\section{FUNCTIONS}

As indicated in the preceding section, there have been variations in the methods and manner of providing $I$ and $R$ services. Although variations still exist, there are primary functions which have been identified as essential to all $\mathrm{I}$ and $\mathrm{R}$ services. ${ }^{19}$ In addition, there are what will be called auxiliary functions. The auxiliary functions are not essential to the existence of an $I$ and $R$ service. They do however provide valuable support and are considered by some to be a necessary part of $I$ and $R$ service. The following outline provides an overview of these functions.

\section{AND R SERVICE}

PRTMARY FUNCTIONS

(1) Development and Maintenance of a Resource File

(2) Direct Service Provision

a. Interviewing

b. Information giving

c. Referral

d. Follow-up

(3) Public Information

(4) Identification of Community Needs/Input Into The Planning Process

AUXILIARY FUNCTIONS

(1) Outreach

(2) Advocacy

(3) Counseling

(4) Reassurance

(5) Transportation

(6) Escort

(7) Telephone Reassurance 


\section{PRIMARY FUNCTIONS}

(1) Development and Maintenance of a Resource File This function consists of:

a. Gathering information that identifies the resources and services available within a given geographic area.

b. Classifying the information so that it is usable and readily available.

c. Providing for an ongoing system of updating and verification of this information.

$I$ and $R$ resource files at the present time range from sophisticated computer systems to simple card file indexes. Whatever form the resource file is in, the primary consideration should be that the information which it contains is accurate and sufficiently detailed for making referrals.

(2) Direct Service Provision

The actual proviston of $I$ and $R$ service can be broken down into four functions: interviewing, information giving, referral and follow-up. Each of the functions is considered essential for $I$ and $R$ service.

a. Interviewing 20

Talking with the consumer to obtain sufficient information to determine: a) the nature of the information being sought, b) the kind of service that may be appropriate, c) the eligibility of the consumer for the service.

b. Information Giving

Providing accurate information to the consumer about the services or organizations that can assist him/her.

c. Referra1

Connecting the consumer to the service provider that can assist him/her, by making a specific appointment for him/her with a service provider.

d. Follow-up

Contacting the consumer and/or service provider following the appointment date made in a referral to determine if contact was made and the service received.

It is recognized that individual $I$ and $R$ providers have interpreted these functions differently and have placed varying degrees of importance on each. Exercises at the end of this chapter will allow for exploration of your agency's interpretations. 
(3) Public Information

The third primary function of an $I$ and $R$ service is to provide information about the service to the public. This would include activities such as the use of public media, newspaper, radio, television, as well as public talks and distribution of posters and handouts. It would also include contacting people in their homes to inform them of the $I$ and $R$ service. Publicity activities should be geared to the characteristics of the geographic area being served, as well as the capacity of the $I$ and $R$ service to respond to community demands. 21

(4) Identification of Community Needs/Input Into the Planning Process

$I$ and $R$ services are in a unique position to identify consumer needs and the gaps in community services. A major function of an $I$ and $R$ service is to provide information to organizations involved in planning for community services. An $I$ and $R$ service may play an active role in the planning process or simply be an information source. 22

\section{AUXILIARY FUNCTIONS}

The auxiliary functions which will be described are provided by $I$ and $R$ services in varying degrees. An $I$ and $R$ service may perform some of these functions or none at all. Some $I$ and $R$ services have working agreements with other agencies which provide these services.

(1) Outreach

Locating individuals in the community in need of $I$ and $R$ services and contacting them in their homes to provide information about community services and to facilitate linkage with needed services.

\section{(2) Advocacy}

Pleading a cause or taking action on behalf of a consumer or a group of consumers to help insure linkage or the establishment of a needed service that is presently not available to the consumer or is nonexistant.

(3) Counseling

Helping an individual to sort out problems and concerns and facilitate resolutions of the problems. Counseling as a function of $I$ and $R$ is only used to enable a consumer to resolve problems which prevent 
him/her from being linked to a needed community service. In this sense, counseling is a very limited but of ten necessary function of $I$ and $R$. Counseling stops when the consumer is linked to the needed service.

\section{(4) Reassurance}

Providing emotional support to insure 11nkage with needed services. This would normally involve talking to the consumer in an encouraging and comforting manner to facilitate linkage with needed services.

(5) Transportation

Providing a ride or reinbursement for a ride in order to get a consumer to needed service.

(6) Escort

Providing a companion to accompany a consumer to needed service.

(7) Telephone Reassurance

Calling a consumer on a regular basis who is isolated or 111 to check on his/her well being.

The importance of these auxiliary functions varies with the population group being served by the I and R service. For the older population, each one of these auxiliary functions merits careful consideration. The significance of providing these services for the older population will be considered in the next section. 


\section{AND R SERVICE FOR THE OLDER POPULATION}

The 01der Americans Act legislation has focused national attention on I and $R$ services for the older population. This emphasis has opened up the question of whether $I$ and $R$ for the elderly should be conceived of differently, than $I$ and $R$ for other population groups. ${ }^{23}$ Since there is little descriptive information available on the actual provision of I and $R$ services to any group, there are no definite answers to this question. It is possible however, to discuss implications for $I$ and $R$ services to the elderly based on knowledge of the older population. The following section will consider the older population and implications for $I$ and $R$ services.

OLDER POPULATION

The older population can be discussed as if it were a group, only in relation to the common experiences which are generally characteristic of growing old in this society. Each older person, however, has an individual and unique way of responding to these experiences. Throughout life, men and women are constantly coping and adapting to changes within themselves as well as changes within their environment. The coping and adapting patterns which men and women establish throughout their lives remain the same in o1d age. These patterns are reflected in individual personalities. $^{24}$ As one author notes, "Older people as a whole, as a result of a long life time of differentiating experiences, tend to be less alike than the members of any other age group..." 25 So, although there are some common changes which generally are experienced by the older population, be aware that: (1) not all older people experience these changes, (2) those who do each respond in an individual way. 
The common changes generally experienced by the older population in this society can be broken down into three areas: physical, social and emotional changes. ${ }^{26}$ These changes will be discussed based on our present older population. Advances in knowledge and changes in attitudes may alter future experiences for the older population.

Physical Changes

There are certain bodily changes which are considered a normal part of growing old. Included would be such things as graying and loss of hair, wrinkled skin, changes in posture, loss of height, loss of teeth, decreases in all senses. 27 In addition to these, there are chronic diseases and disabilities which are experienced by the older population. In 1971 , approximately $85 \%$ of the population over 65 living in the community had one or more chronic conditions. Of this population, $20 \%$ experienced interference with their mobility. It is reported also that persons over 65 have twice as many hospital visits and lengthier stays than younger persons. 28

\section{Social Changes}

There are major changes in roles and a decline in social interaction as a person grows old in this society. With retirement from work, there is a decline in income as well as a decline in opportunities for social interaction and purposeful activity. In a society which glorifies youth and values productivity in work, the retired person often experiences a loss in his/her sense of usefulness and self esteem. 29 . Lowered income is a severe problem for many older persons. Approximately $22 \%$ of persons over 65 lived in households with incomes below poverty level for 1971. The older population is highly vulnerable to the loss of spouses and other significant persons through death. In $1972,52.8 \%$ of women over 65 were widowed and $15.7 \%$ of men. 30 Many older persons face problems of social isolation.

\section{Emotiona1 Changes}

The social and physical changes compounded by unsupportive societal attitudes, may precipitate emotional changes in the older person. These changes may be experienced in grief, depression or anxiety. 31

Compared to younger population groups, older people "... are poorer economically, have more health problems (physical and menta1), experience more interpersonal losses, and lose status and social roles more than any other population group." 32 
IMPLICATIONS FOR I AND R SERVICE

It appears that the older population may have a greater need for $I$ and $R$ services than other populations groups. There is nothing to suggest, however, that basically $I$ and $R$ services should be conceived of differently for the older population. ${ }^{33} \mathrm{~A} 11 \mathrm{I}$ and $\mathrm{R}$ services are directed at individuals who have problems and needs. The primary and auxiliary functions are the same for any $I$ and $R$ service. However, the emphasis placed on particular $I$ and $R$ functions may change when the service is directed at the older population. In reviewing some of the common characteristics of the elderly, 1t appears that there are certain $I$ and $R$ functions that should receive special attention.

Public Information: Outreach

It has been suggested that the older population is more difficult to reach with $I$ and $R$ service than other age groups. ${ }^{34}$ Factors contributing to this for the older population include: greater social isolation, restricted mobility, lack of transportation, lack of education and experience in dealing with social service agencies, lowered self-image and diminished personal strengths. An I and R service for the older population should emphasize the public information function. Speclal methods for reaching the older population should be adopted. The use of outreach, bringing the I and $\mathrm{R}$ service to the individual in his/her home, should be used in reaching the older population.

Interviewing and Assessment: Counseling, Reassurance Multiple changes faced by the elderly, combined with lowered self image 
and diminished personal strengths may make the delivery of $I$ and $R$ services to the older population more difficult. Additional help in sorting out problems and providing reassurance is indicated for the older population.

\section{Referra1: Advocacy, Transportation, Escort}

Linkage with the appropriate community service providers may warrant extra attention with the older population. Restricted mobility, lack of income, lack of transportation, decreased physical and emotional energy are all factors for the older population which may hamper successful linkage with a service provider. Emphasis on a supportive referral process is indicated for the older population. Added support through advocacy, provision of transportation and escort service should be considered.

\section{Follow Up: Telephone Reassurance}

The same problems which affect the older population's use of I and R services, may affect its use of other social services. Follow up, to insure that linkage has been made with needed service should be emphasized in $I$ and $R$ service for the older population. The added support of contact through telephone reassurance may make future referrals to necessary services possible.

Again it should be stressed that, basically, I and R services should be conceived of the same for the older population as any other population group. There are some common characteristics of the elderly which imply an emphasis on particular $I$ and $R$ functions. However, since $I$ and $R$ 
services deal with individuals who have unique personalities, there can be no set formula or definite pattern of $I$ and $R$ service delivery for all. The skills of the $I$ and $R$ worker to assess and accurately respond to the individual is the critical element in successful delivery of $I$ and $R$ services. 
ROLE OF THE I AND R WORKER

An $I$ and $R$ worker is the link between a person in need of service and the appropriate service available in a community. An I and R worker's ability to interview, assess and successfully link a person in need to an appropriate resource is the primary $I$ and $R$ service. Other services provide more tangible products, but with $I$ and $R$, the only service is the $\mathrm{I}$ and $\mathrm{R}$ worker and his/her ability to link a person with a service provider. The activities of the $I$ and $R$ worker in relation to the consumer, will normally include the following: (1) providing answers to direct questions, (2) discussing problems or concerns to determine what service is needed, (3) providing information about community resources, including directions on how to get to a service, (4) providing detailed information about eligibility requirements and application procedures of community services, (5) making referrals, (6) making follow up contacts to determine if the consumer was linked to a needed service. ${ }^{35}$

In order to carry out this job, an I and $R$ worker needs a knowledge of community resources and interviewing skills. The next two chapters of this manual will focus on the interviewing process. A knowledge of community resources can be obtained in the following ways:

a. Thoroughly knowing the resource file and continually updating resource information.

b. Learning through reading and listening to local news. Sources would include: newspaper articles, radio, television, community bulletin boards, news bulletins or flyers sent out by community groups.

c. On the job training sessions.

d. I and $\mathrm{R}$ work experience. Working through a complex problem with 
a consumer is one of the best ways to get to know the resources available in a community, and the correct persons to contact for help.

The ability of the I and $R$ worker to interview, assess and apply his/ her knowledge of community resources is the basis of an $I$ and $R$ service. The information contained in the next two chapters should provide a framework to help the $I$ and $R$ worker carry out the job. 


\section{EXERCISES}

\section{HISTORY}

(1) What is the background or history of your I and R service?

You may want to check with your supervisor to find out:

Why and when your service was organized?

What is your funding source?

What is the stated purpose of the service?

What are the goals of the service?

\section{FUNCTIONS}

(2) How do the primary and auxiliary $I$ and $R$ functions reviewed in the text compare to your service?

Consider how your service interprets the functions by answering the following questions.

Development and maintenance of a resource file:

Who is responsible for gathering resource information?

How is this done?

How is the resource file updated? How of ten?

Who is responsible for correcting information in the file?

How is resource information classified?

Is there a system for cross referencing information?

\section{Service Provision:}

Does your service have any specific guidelines for interviewing and information gathering?

How are referrals made by your service?

Does your service do follow up? How is it done?

\section{Public Information:}

How is the public made aware of your $I$ and $R$ service?

Identification of community needs/Input into the planning process:

What type of records does your service keep on the needs of consumers? What is the purpose for your record keeping?

What role does your service play in planning for community services? 


\section{Auxiliary functions:}

Does your service provide any of these functions?

If your service does not, review the resource file to find out what service in the community does.

\section{OLDER POPULATION}

(3) Listed below are hypothetical examples of special circumstances that may occur with requests from the older population. How would your $I$ and $R$ service handle these situations?

a. You have made a referral to Food Stamps for Mrs. Jones but she is without transportation to get there.

b. A man calls to report that he thinks his 78 year old neighbor, $\mathrm{Mr}$. Peter, is without food and will not accept help from his neighbors. Mr. Peter has no telephone.

c. Mr. Harvey wants to go to the local lunch program for seniors but he is in a wheelchair and needs special transportation to get there.

d. Mrs. Roth wants to apply for SSI benefits but she is afraid to go to the office alone, she says she gets confused when asked many questions. She has no friends to go with her.

\section{RESOURCE FILE}

(4) Practice using your resource file by looking up information for the hypothetical requests listed below. Locate the community services to which you might refer consumers who had these requests. Locate the name, address, telephone number, eligibility and application procedure of the service.

a. Social Security retirement check is late in arrival.

b. A woman needs someone to come to her home to give a weekly injection.

c. Schedule and location of local dances for seniors.

d. Information about the costs and services available at local nursing homes.

e. Weekly housekeeping assistance for an elderly man.

f. Where to apply for reduced senior rates at national parks.

g. A need for someone to stay with an 80 year old bedridden man while his wife goes grocery shopping. 


\section{REFERENCES}

${ }^{1}$ For further discussion of $\mathrm{I}$ and $\mathrm{R}$ definitions see Nicholas Long et a1., Information and Referral Centers: A Functional Analysis 3d Ed, (Washington, D.C.: Administration on Aging, DHEW, 1972), p. 1; Eileen Byrne McVeigh, A Systems Approach to Information and Referral Book Five: Staff and Volunteer Training Methods For Information Giving and Referral (Florida: Project IN-STEP, 1974), p. 1; United Way of America, National Standards. Information and Referral Services (Virginia: United Way of America, 1973), p. 1.

2 McVeigh, p. 1.

${ }^{3}$ Long et a1., p. 1 .

${ }^{4}$ Cooper and Company, Costs and Benefits of Information and Referral (Washington, D.C.: Administration on Aging, DHEW, 1975), p. 22.

5 The outline has been adapted from Long et al., pp. 24-25.

6 The Assistance Group, Information and Referral Training for State Units on Aging (Maryland: The Assistance Group, 1975), Sec. II, p. 1.

${ }^{7}$ Long et a1., p. 2 .

8 Ibid., p. 4 .

${ }^{9}$ The Assistance Group, Sec. II, p. 5.

${ }^{10}$ National Association of Citizens' Advice Bureaux (London: National Association of Citizens' Advice Bureaux, 1975), p. 2.

11 Long et a1., pp. 2-3.

12 Ibid., p. 4 .

${ }^{13}$ National Easter Seal Society for Crippled Children and Adults, $I, R$ and F Programs in the Easter Seal Society (Illinois: National Easter Seal Society for Crippled Children and Adults, 1973), pp. 1-5.

${ }^{14}$ The Assistance Group, Sec. II, p. 7.

${ }^{15}$ Ibid., Sec. II, p. 8 .

${ }^{16}$ Ibid.

17 Older Americans Act of 1965 as Ammended, U.S. Code. Secs. 304-305 (1973).

18 The Elements eistablished by the Administration on Aging pertain 
to the following catagories; organization - facilities, resource file, staffing, access, interviewing - information giving - referral, publicity outreach, follow-up, escort - transportation, records - reports. Administration on Aging PI 75-9, August 28, 1974, Administration on Aging IM 75-10 August 28, 1974.

${ }^{19}$ For further discussion of $\mathrm{I}$ and $\mathrm{R}$ functions see Cooper and Company, pp. 36-54; Long et a1., pp. 12-18.

${ }^{20}$ Definitions have been adapted from handouts given at Oregon State University, "I and R Definitions" Nutrition Training Program, April

1975, (Typewritten)

${ }^{21}$ Long et a1., pp. 15-16.

22 Ibid.

${ }^{23}$ Cooper and Company, p. 24.

${ }^{24}$ Elaine M. Brody and Stanley J. Brody, "Decade of Decision for the E1derly," Social Work 19 (September 1974), p. 547.

${ }^{25}$ Estelle F. Booth, Reaching Out to the Hard-to-Reach 01der Person (California: San Francisco Senior Center, 1967), p. 4.

${ }^{26}$ Robert N. Butler and Myrna I. Lewis, Aging and Mental Health (Saint Louis: The C.V. Mosby Company, 1973), p. 19.

27 Ibid.

${ }^{28}$ U.S. Department of Health, Education and Welfare, New Facts About older Americans (Washington, D.C.: Administration on Aging, DHEW, 1973) (pamphlet).

${ }^{29}$ Brody and Brody, p. 548 .

${ }^{30}$ Administration on Aging, New Facts.

31 Butler and Lewis, p. 20.

32 Brody and Brody, p. 545.

${ }^{33}$ Cooper and Company, p. 31.

${ }^{34}$ Ibid.

${ }^{35}$ Frances B. Gilbert, Information and Referral How to Do It, Vol 1 Draft (Virginia: Health-Welfare-Recreation Planning Council of the United Communities, 1975), p. 210. 
CHAPTER II

I AND R SERVICE PROVISION:

THE PROCESS 


\section{AND R INTERVIEWING}

$I$ and $R$ service is provided within the framework of the interviewing process. This process includes talking with the consumer to obtain sufficient information to determine: (1) the nature of the consumer's needs; (2) the kind of service that may be appropriate; (3) the eligibility of the consumer for the service. It also includes linking the consumer to the needed service by information giving, referral and follow up.

Along with a knowledge of community resources, the $I$ and $R$ worker needs skills in interviewing to carry out this job. Most people possess some abilities in interviewing, since it is a form of interaction we are often involved in. When we shop for a particular item, we may interview a salesperson to elicit information about the item. When we have a doctor's appointment, we are interviewed by the doctor to determine the nature of our illness. Usually, we are not conscious of our interviewing abilities in these daily situations. However, for the $I$ and $R$ worker, interviewing is the basic tool used to provide $I$ and $R$ service. The worker should be aware of how his/her ability to interview affects interaction with the consumer.

Interviewing skills are acquired and improved through practice, along with a knowledge of interviewing theory. Knowledge of some of the dimensions of the process provides the worker with a basis for assessing and improving his/her interviewing practices. 1 
Since interviewing involves individuals who are each unique, there are no rigid formulas for interviewing that are applicable to al1. ${ }^{2}$ There are, however, some basic dimensions of the process which provide a framework for interviewing techniques and practices. These dimensions will be considered in this chapter. The last chapter will review some specific interviewing techniques. 


\section{DEFINITION - INTERVIEW}

An interview has been defined as a conversation which is directed at achieving a particular purpose. The purpose may be decided upon prior to the interview or during the interview. ${ }^{3}$ The interaction which takes place is distinguished from daily conversation for the following reasons:

(1) The content is focused on achieving the purpose of the interview.

(2) One person has responsibility for consciously directing the interview towards achieving the purpose.

(3). The interview is focused primarily on serving the needs of one person. 4

An $I$ and $R$ interview normally takes place between the worker and the consumer. * The $I$ and $R$ interview is a two way conversation for the purpose of determining the nature of the consumer's needs and linking the consumer to an appropriate service provider. ${ }^{5}$ The interaction between the worker and the consumer is directed towards achieving this purpose. The worker is responsible for directing the interview towards serving the needs of the consumer.

* The I and $\mathrm{R}$ interview may take place between the worker and several consumers or a representative of the consumer. 


\section{COMMUNICATION PROCESS}

Interviewing is a communication process. ${ }^{6}$ There is interaction and an exchange of ideas between two persons. The $I$ and $R$ worker and the consumer transmit ideas or messages back and forth to one another. These messages are sent primarily in the form of speech. * A message which is sent by one person triggers a response in the person who receives it. In this process, the person sending a message wants the person receiving it, to understand the meaning behind his/her idea in the same way that $\mathrm{s} / \mathrm{he}$ understands it. This is a dynamic and complex process. The meanings which people assign to words depend upon their background, their perception of the person who is speaking and the situation in which the communication takes place. 7

The following illustrations depict the communication process. Remember, these illustrations present a very static picture of what is a dynamic process. The illustrations are an attempt to emphasize the main dimensions of this process and increase your understanding of what takes place in the $I$ and $R$ interview.

* Some considerations for non-verbal communication will be made in Chapter III. 


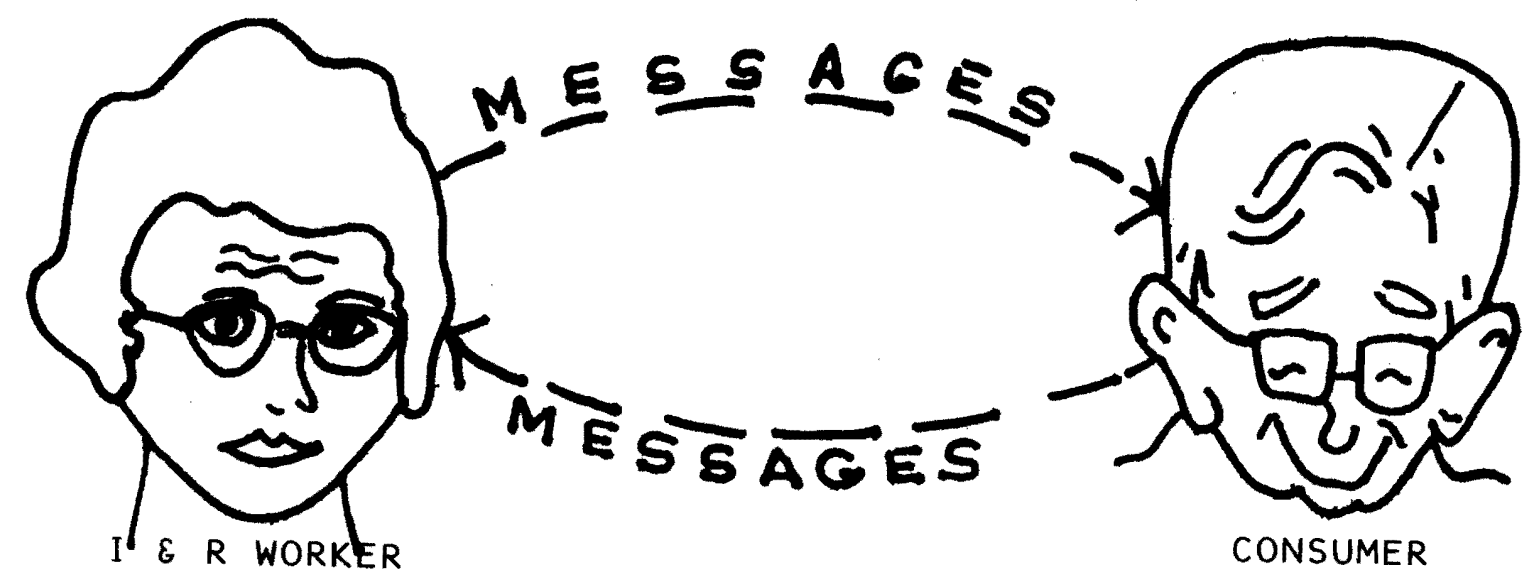

1) COMMUNICATION IN THE INTERVIEW

In the interviewing process, the worker and the consumer send, receive and process messages. A message is sent by one person, received by the other and processed or interpreted. On the basis of how it is received and processed, a response message is formulated and sent. Each of these steps will be considered in detail in the following illustrations.

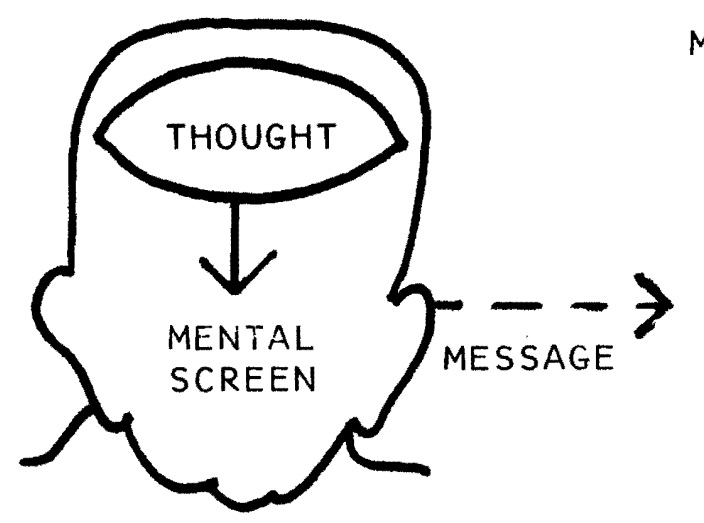

MENTAL SCREEN:

BACKGROUND

ATT I TUDES

VALUES

2) SENDING MESSAGES

A message originates as a thought in the mind of the consumer. Within the framework of the consumer's mental screen, meaning is given to the thought. Since we are each different in the composition of our attitudes, background and values, the meaning given to the thought is an individual process. This same individuality applies in the choice of words and the manner in which this message will be sent. Before a message is sent, it is reviewed by the consumer's mental screen and his/her perceptions of the worker and the interviewing situation. Some of the more common factors that affect how messages are sent are: fear of rejection, inability to verbalize emotionally laden topics, and concern about the other person's expectations. The words that are chosen to verbalize a message usually reflect a person's background; sex, age, race, and occupation. The meaning which a message has for the sender and the manner in which it is sent is unique to the individual. 


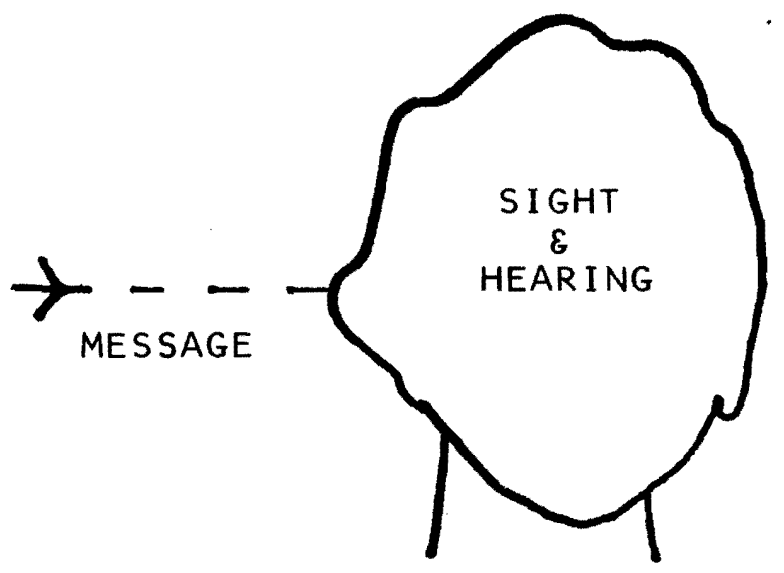

3) RECEIVING MESSAGES

Messages are received primarily through the senses of sight and hearing. For telephone interviews, this is limited to the sense of hearing. In this process, there are some problems which may arise that prevent or distort messages from being received. The more common problems are: (1) the receiver has a hearing or sight impairment; (2) there is interference in the environment, for example a distraction in the background or static over the telephone; (3) the receiver was not really listening to the sender. A message which is sent may be received in part or not at all.

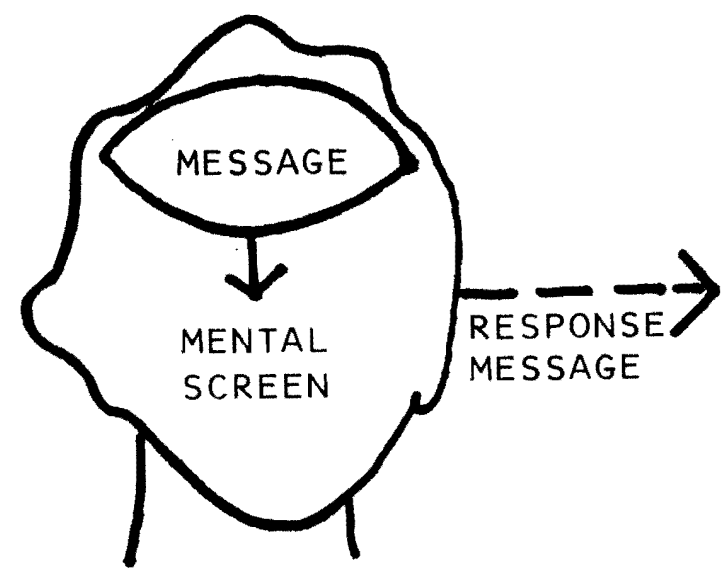

MENTAL SCREEN:

BACKGROUND

ATTI TUDES

VALUES

4) PROCESSING MESSAGES

Once a message has been received, it has to be processed or given meaning. The receiver processes the message in the framework of his/her background, attitudes and values. The receiver also defines the message based on his/her knowledge of the sender and the circumstances in which the interview is taking place. Based on the interpretation of the message, the receiver formulates a response message. The meaning which is given to a message by the receiver is also an individual process. 
The communication process is complex due to the many individual factors which enter into the process. Attaining an understanding of one another's thoughts is difficult. In fact, in view of the many factors, it is amazing how well we are able to communicate with one another. A person receiving a message can, at best, formulate a meaning which closely approximates that of the sender's. For the $I$ and $R$ worker, attaining this close approximation is critical. Since the purpose of the $I$ and $R$ interview is to understand the consumer's needs, the worker must understand the meanings behind the messages which the consumer sends.

The $I$ and $R$ worker can increase the chances that meaningful communication will take place in the interview if: (1) $\mathrm{s} / \mathrm{he}$ has an appreciation and understanding of the factors which affect the communication process; (2) s/he actively works to control these factors in the interview situation. The remainder of this chapter will explore some of the dimensions of this process. 


\section{A HELPING RELATIONSHIP}

Another factor which affects the communication process is the feelings between the $I$ and $R$ worker and the consumer. The communication process consists not only of sending, receiving and processing messages, but includes the emotional context in which the process takes place. The feelings which the worker and consumer have for one another can positively or negatively affect the communication. These feelings or

the emotional interaction between the two is called a relationship. 8

If the relationship is positive, an atmosphere is created for the interview in which the consumer feels safe, trusting, and able to express him/herself. If the relationship is negative, the atmosphere is such that the consumer feels mistrustful, defensive and less able to freely discuss problems and concerns. 9

Since the worker is concerned with helping the consumer eliminate barriers which prevent him/her from obtaining needed services, a positive relationship should be established. In order to explore the consumer's needs, which may include a discussion of highly emotional issues, the worker should develop a rapport which frees the consumer to discuss these concerns. The consumer will be more apt to use the community service information if $\mathrm{s} / \mathrm{he}$ feels a sense of trust in the worker. Even in those cases where the worker provides only simple information, it is helpful if the consumer feels appreciated and respected. Where this has been accomplished, the consumer will be more likely to use the information and will feel comfortable in calling the $I$ and $R$ service in the future. 
The relationship provides the context in which communication takes place. This relationship is developed through the behavior which the worker demonstrates towards the consumer. Since the worker is dealing with individuals, there is no set prescription of what this behavior should be. There are, however, certain types of behavior which the consumer has a right to expect from the worker. In demonstrating this behavior, the worker helps to insure that a positive relationship will develop. A description of these consumer rights should provide guidelines from which the worker can model his/her behavior. 


\section{CONSUMER'S RIGHTS}

The consumer has a right to expect certain behavior from the $I$ and $R$

worker. This behavior should demonstrate to the consumer the follow-

ing:

(1) INDIVIDUALITY

The consumer has a right to be treated as a unique individual. The consumer may have needs which are similar to other people's. However, the worker should recognize that each person differs in the way $s /$ he experiences the need. The worker's behavior should demonstrate to the consumer that $s /$ he is appreciated as an individual. Any information which is provided to the consumer should be geared to the individual's situation.

In working with the older population, there will be similarities in needs and requests. However, no two requests will be exactly alike. Consequently, the worker should not predetermine the consumer's needs before s/he has a chance to explain them.

\section{(2) CONCERN}

The worker should demonstrate to the consumer a sincere interest and concern. During the interview, the consumer should feel that $\mathrm{s} /$ he is an important person to the worker. The worker demonstrates this through carefully listening and responding to what the consumer is saying.

For the older person, who may fear rejection and have diminished personal strengths, a sincere and concerned interest on the part of the worker may be the key to establishing a positive helping relationship.

(3) NON- JUDGMENTAL

The consumer has a right to expect that the worker will listen to his/her needs and respond to the request without criticizing or passing judgment.

It may be difficult at times to withhold an opinion when we feel strongly about a particular situation. However, the worker must remember that each person has his/her own set of values. It is not the I and R worker's role to impose his/hers on the consumer.

(4) SELF-DETERMINATION

The consumer's ability to solve his/her problems must be recognized and acknowledged. The worker is available to assist but not to make the consumer's decisions.

In dealing with the older consumer, the worker should recognize 
that although the consumer may be vulnerable at the moment, s/he has had a whole lifetime of experience in adapting and coping. The worker's role is to enable the consumer to make decisions, not to make the decisions for him/her.

\section{(5) EMPATHY}

The $I$ and $R$ worker has a responsibility to understand the consumer's situation from the consumer's point of view. The worker should attempt to view the consumer's situation as if $\mathrm{s} / \mathrm{he}$ were looking through the eyes of the consumer.

The younger worker who is dealing with the older consumer has the capacity to do this. The worker may not have had all the experiences of an older person, however, the worker can understand the consumer's situation by carefully listening, observing and mentally placing himself/herself in the situation.

(6) COURTESY

The consumer has the right to be treated in a courteous and respectful manner. The worker is in the position of serving the consumer.

The older person who is confused or disoriented has the same right to be treated with respect and dignity. The worker should avoid calling the older person by his/her first name. Although this may be appropriate in some cases, the older person may feel that the use of the title Mr., Mrs., or Miss is a sign of respect.

(7) EFFICIENCY

The consumer has a right to expect prompt and competent service. The worker must keep a11 commitments. If information and/or a referral is provided, it must be accurate and in sufficient detail to be of assistance to the consumer.

Additional effort may be required with the older person who has a sight or hearing impairment. It is the worker's responsibility to make sure that the consumer has heard and understands any information which has been provided.

(8) CONF IDENTIALITY

The worker must treat all information which the consumer has provided in a confidential manner. This means that all information, including the consumer's name, will not be shared with anyone outside the $I$ and $R$ service staff. With the staff, information should be shared only with those members who will be involved in providing service to the consumer. In these cases, only information which is necessary to provide the service should be shared. The consumer's consent must be obtained before sharing any information outside the $I$ and $R$ service. In asking for consent, the 
worker must clearly specify who the information is to be shared with and how it will be used. Confidentiality is a basic right of the consumer. It is essential for maintaining the integrity and good standing of the $I$ and $R$ service in the communtty.

The older person who is involved in reminiscing and reviewing past experiences may wish to share some of this information with the worker. Although some background information may be valuable in understanding the consumer's present situation, this information is probably not appropriate to be shared in detail with other persons who will be involved in providing service. Share only information which is essential in order to insure linkage with an appropriate service provider.

The $I$ and $R$ worker who demonstrates this behavior provides a framework in which a positive relationship can grow. Some specific techniques for interviewing behavior will be discussed in Chapter III. It is important to consider first, however, that the worker's ability to demonstrate desired behavior is dependent to a great extent upon his/her attitudes. Although the worker's behavior directly affects the interview process, the worker's attitudes often control his/her behavior. 
WORKER'S ATTITUDES

Underlying the $I$ and $R$ worker's behavior are his/her attitudes. Attitudes consist of the feelings either positive or negative, which we have towards ourselves, other people, situations and things. Some attitudes are felt more strongly than others. Our attitudes are reflected in our behavior. The worker's attitudes may help or hinder the interview process. For instance, if the worker gets frustrated with people who talk in low, slow voices, s/he may express impatience with the consumer who speaks that way. Our attitudes however, do not have to control our behavior if we are aware of how attitudes affect our behavior and we actively work to control these attitudes in particular situations. 10

The $I$ and $R$ worker should have an understanding of his/her attitudes towards the consumer population. A self-awareness exercise at the end of this chapter should help in attaining this understanding. An awareness of one's attitudes is a first step. The worker must next observe how these attitudes affect his/her behavior. The worker can assess behavior by comparing it to the list of consumer's rights. If the behavior is contrary to the rights, the worker must consider changing his/her behavior. Each person has a right to his/her own attitudes and opinions. However, in the interview situation when the purpose is to fully understand the consumer, the worker's personal attitudes must be put aside. The worker should actively attempt to understand the consumer. This is not to imply that the worker must accept or condone the consumer's behavior. The worker must attempt to understand 
the feelings and meaning behind the behavior. ${ }^{11}$ In order to do this, the worker must refrain from applying his/her personal attitudes to the consumer.

An awareness and understanding of one's attitudes towards the consumer population is an important step. Controlling any attitudes which may be detrimental to the interviewing process must be actively worked on.

For the $I$ and $R$ worker who will be dealing with people of other races and cultures, it is important to recognize that there may be major differences in background and experiences. There may also be language barriers. These differences can limit the interview process. However, there are ways of bridging these differences. The worker may assume as a responsibility: (1) reading materials about the race and culture; (2) being more aware of one's attitudes and behavior towards people with racial differences; (3) being more open to carefully listening to and observing the consumer before making an assessment. ${ }^{12}$

In summary, the $I$ and $R$ interview with its purpose of linking the consumer to needed services requires that the worker focus his/her attention on serving the consumer. To accomplish this, the worker may have to put aside personal attitudes and values and direct his/her energy on developing a relationship in which the consumer's needs can be openly explored and understood. 
EXERCISES

\section{COMMUNICATION PROCESS}

(1) Consider the meanings which you give to messages sent by consumers.

Listed below are three messages which might be sent by consumers. Also listed are sets of circumstances in which the messages are sent. Consider each message and then choose a set of circumstances for the message. Combine different sets of circumstances using the same message. Consider how the meaning changes.

\begin{tabular}{|c|c|c|c|}
\hline & \multicolumn{3}{|c|}{ CIRCUMSTANCES OF COMMUNICATION } \\
\hline MESSAGES & $\begin{array}{l}\text { INTERVIEW } \\
\text { SITUATION } \\
\end{array}$ & $\begin{array}{c}\text { CHARACTER ISTICS } \\
\text { OF SPEAKER }\end{array}$ & $\begin{array}{c}\text { SPEAKER'S TONE } \\
\text { OF VOICE }\end{array}$ \\
\hline $\begin{array}{l}\text { "I need a } \\
\text { ride." }\end{array}$ & $\begin{array}{l}\text { Telephone call } 4: 45 \mathrm{pm} \\
\text { office closes at } 5\end{array}$ & $\begin{array}{l}60 \text { yr. old man } \\
\text { works part time }\end{array}$ & Gruff, abrupt \\
\hline $\begin{array}{l}\text { "I hear you } \\
\text { can get a } \\
\text { home } \\
\text { delivered } \\
\text { meal." }\end{array}$ & $\begin{array}{l}\text { Office Interview } \\
\text { in Senior Center, } \\
\text { consumer stops by } \\
\text { after playing } \\
\text { cards }\end{array}$ & $\begin{array}{l}80 \text { yr. old woman } \\
\text { confined to } \\
\text { wheelchair }\end{array}$ & Soft, timid \\
\hline $\begin{array}{l}\text { "They wanted } \\
\text { to know } \\
\text { everything } \\
\text { about me." }\end{array}$ & Consumer's home & $\begin{array}{l}75 \text { yr. old woman } \\
\text { has difficulty } \\
\text { speaking English, } \\
\text { she speaks a } \\
\text { foreign language }\end{array}$ & Angry \\
\hline
\end{tabular}

\section{HELPING RELATIONSHIP}

(2) Is it your responsibility to try to develop a positive relationship with the consumer. Place yourself in the consumer's role and consider how you would feel if you got the following responses when calling an I and R service. Would you feel welcome, comfortable and willing to share your concerns?

\section{TELEPHONE INTERVIEW}

1. Receptionist answers transfers you to an $I$ and $R$ worker. The worker comes on the line and immediately asks you if you can hold a minute. You wait 3 minutes.

2. Pleasant voice answers, says, "May I help you?" 
3. Rushed voice answers, says, "This is Mr. Jones."

OFFICE INTERVIEW

4. Worker smiles, indicates where you should sit. She asks, "How are you today?"

5. Worker seems pleasant, gives you her name and says, "If you don't mind, before we start talking, I would like to check one thing for a gentleman who just left." She rushes off.

\section{SELF-AWARENESS}

(3) The purpose of the following exercise is to increase your awareness of the attitudes and feelings which you hold towards the consumer population you will serve. Self-awareness increases your ability to control and understand your behavior and feelings in the interview situation. It should enhance your ability to relate in a non-judgmental way.

A WORD OF CAUTION This exercise is not intended to imply that certain attitudes are right or wrong, good or bad. Your attitudes and feelings are part of you. This exercise is intended only to increase your awareness of attitudes and feelings which may enter into your job performances as an $I$ and $R$ worker.

Exercise:

a) Go through your resource file. Think about the various categorles of service which you may refer people to. List these categories. Next to them, write down your reactions or attitudes towards each one.

(For example: alcoholic's services - your reactions counseling services - your reactions)

b) Next, consider various characteristics of people which you have heard others pass judgment on or express strong opinions about. List these characteristics. Next to these, write your reactions or attitudes. 13

(For example, people who are:

confused

poor

drug addicts

aggressive

fat

skinny

old

of a particular race or ethnic origin, etc.) 
c) Now consider your reactions. Can you control your personal feelings or reactions in the interview situation?

Will your attitudes or feelings impair your ability to deal with people in a nonjudgmental way? 
REFERENCES

${ }^{1}$ Annette Garrett, Interviewing Its Principles and Methods 2nd ed., rev. Elinor Zaki and Margaret M. Mangold (New York: Family Service Association of America, 1972), p. 5.

2 Ibid.

${ }^{3}$ Alfred Kadushin, The Social Work Interview (New York: Columbia University Press, 1972), p. 8.

${ }^{4}$ Ibid.

${ }^{5}$ Diane C. Tessari et al., Information and Referral Services: Information Giving and Referral rev. 2nd ed., working draft (Washington D.C.,: Administration on Aging, DHEW, 1974), p. 1.

${ }^{6}$ For further discussion of the communication process see Kadushin, p. 25 .

${ }^{7}$ Colin Cherry, On Human Communication 2nd ed. (Massachusetts: Massachusetts Institute of Technology, 1966), pp. 10-11.

${ }^{8}$ Kadushin, p. 41 .

${ }^{9}$ Ibid.

10

${ }_{\text {Garrett, p. } 25 .}$

${ }^{11}$ Ibid., p. 27.

${ }^{12}$ Alfred Kadushin "The Racial Factor in the Interview" Social Work 17 (May 1972), p. 91.

${ }^{13}$ Exercise adapted from Garrett, p. 24. 
CHAPTER III

I AND R SERVICE PROVISION:

INTERVIEWING TECHNIQUES 


\section{INTERVIEWING SKILLS}

Within the framework of the interview process, the $I$ and $R$ worker uses his/her interviewing skills to obtain an understanding of the consumer's needs in order to link the consumer to a needed community service. Interviewing skills are acquired through practice and review of interviewing techniques. These techniques or suggested methods for interviewing are based on the experiences of others.

The newer worker may find that using specific interviewing techniques requires a conscious effort. However, as the worker gains experience, these techniques become a comfortable part of the way $s /$ he interacts with the consumer. The worker also learns through experience that because each consumer is unique, there is no set method for interviewing that is applicable for all persons. The worker will learn to selectively apply interviewing techniques to each situation. 1

The following chapter will first consider the situations in which the $I$ and $R$ interview takes place. Then techniques for interviewing will be discussed. For the purposes of discussion, the interviewing process has been divided into four stages; beginning the interview, information gathering, information giving and referral, and terminating the interview. In practice, there is not a clear division between these stages because interviewing is a dynamic process. 


\section{INTERVIEW SITUATION}

$I$ and $R$ interviews are normally conducted over the telephone, face to face in the $I$ and $R$ office, or in the consumer's home. Although the basic interviewing process remains the same, each one of these situations adds a different dimension. The worker should give some thought to the situation in which an interview is to take place.

\section{TELEPHONE INTERVIEWS}

In telephone interviews, the worker is limited in having only his/her sense of hearing to use in receiving the consumer's messages. Careful listening is a must. To the consumer, the worker's voice is the $I$ and $R$ service. Therefore, in using the telephone, it is particularly important to remember the following:

(1) Identify yourse1f. Since the consumer cannot see who the worker is, an introduction should be made. The worker should give his/her name and, if appropriate, identify that $s /$ he is the $I$ and $R$ worker.

(2) Ta1k distinctly.

The worker's voice is the $I$ and $R$ service to the consumer. If the worker is talking too fast, too quietly, or is chewing gum, the consumer may not be able to understand what is being said.

(3) Don't leave the line for long.

In telephone interviews, it is particularly important that the worker be prepared before the conversation begins. 
Materials and resource information should be handy. If the worker leaves the line, the consumer should be informed where s/he is going. No one likes to be left for a long time holding a phone instrument. The worker should not be gone from the line for more than a few moments. The worker should also be careful of how $s /$ he uses the phone instrument. If there is a hold button, it should be pressed down when the worker is off the line. A telephone receiver will transmit sound even if the mouthpiece is covered with a hand or pressed against the chest. If the receiver is laid on a desk top without being placed on hold, the consumer will probably hear the office conversation. ${ }^{2}$

\section{OFFICE INTERVIEWS}

In the office setting, the worker should determine that there is sufficient privacy and freedom from noise and interruptions to conduct the interview. The consumer's right of confidentiality is not satisfied if everyone in the office can overhear the conversation. The worker should try to arrange for someone else to answer his/her telephone during the interview. Continual interruptions are frustrating for the consumer and they may limit exploration of the consumer's needs.

HOME INTERVIEWS

Observing the consumer in his/her home environment is an added advantage for the worker in understanding the consumer's needs. The home interview will be more social in nature and less formal than the office interview. This may serve as an advantage to the worker in developing a 
relationship with the consumer. A disadvantage in the home interview, however, may be frequent interruptions from other family members, pets or telephone calls. Since the worker is a guest in the consumer's home, s/he must be sensitive to the social customs observed in the home. The timing of a home interview is very important. The worker should try to avoid interrupting the consumer's routine activities.

Home interviews may be initiated by the consumer or by the worker. If the interview is initiated by the worker, calling for an appointment or sending an introductory letter serves as an opening. If the worker goes to the home without an appointment, careful explanation needs to be made to the consumer regarding the worker's identification and the purpose of the visit. The consumer may decide not to let the worker in.

The policy of the I and R service normally dictates the type of situation in which the interview takes place. In any of these situations, it is important that the worker has done some pre-planning and is prepared with the necessary forms and materials. 
BEGINNING THE INTERVIEW

A good beginning for an interview is important. The opening interaction sets the tone for the communication which will follow. It is much easier to build on a good beginning than to try to make up for a bad start. ${ }^{3}$

In beginning the interview, the worker might consider how the consumer feels when $s /$ he calls or comes in for the first time.

- it isn't easy to ask for help

- it isn't easy to receive help

- it isn't easy to trust a stranger

- it is often difficult to see one's problems clearly

- it is difficult to share one's problems

Making the initial contact may be very difficult for the consumer. In asking for help, the consumer may feel inadequate or fearful that the worker will think s/he is incapable of handling his/her own problems. 5

For the older person who has diminished personal strengths and who fears losing his/her independence, contacting the $I$ and $R$ service is a difficult step. These considerations may help the worker understand the consumer.

The worker might also consider what $s /$ he represents to the consumer. The consumer may view the $I$ and $R$ worker:

- as a helper

- as part of the welfare bureaucracy

- as a last hope

- as the authority - a person with the answers

- as the first attempt at asking for help

The worker should be aware that consumers will have different expectations of the I and R service. The worker should be sensitive to these 
expectations and realistically convey from the beginning what it is the $I$ and $R$ service can do.

In starting the interview, the worker should consider the following.

(1) Set a tone in which the consumer feels comfortable and welcome. The worker should convey in his/her voice warmth and friendliness. The worker should try to be relaxed and at ease if $\mathrm{s} / \mathrm{he}$ wishes the consumer to feel that way. A worker who is rushed and preoccupied with an earlier occurrence might take a second at the start of each interview to remind him/herself that this is a new person. This person deserves the worker's full attention.

The worker should start the interview by giving the consumer his/ her name. It may be appropriate also for the worker to indicate that $s /$ he works for the $I$ and $R$ service. If the consumer has gone through a receptionist and has had to wait, s/he may be confused about who the worker is. After identifying him/herself, the worker may want to use a phrase that invites the consumer to proceed. This is not necessary if the consumer has begun to explain why $s /$ he has called. If appropriate, however, the worker might want to use a phrase such as, "May I help you?" Whatever opening remark is used, the worker's tone of voice and facial expression should indicate interest and willingness to listen. 
(2) Listen to the consumer's opening remarks.

Carefully listen to what the consumer says and how $s /$ he says 1 . The opening remarks are the clue to how to proceed with this individual. The remarks may indicate how the consumer feels about using the $I$ and $R$ service. The consumer will usually start the interview in one of the following ways:

a. stating his/her needs

b. asking what the $I$ and $R$ service can do

c. asking for specific information

d. explaining who told $\mathrm{him} / \mathrm{her}$ to call

e. discussing a concern

f. making a friendly comment

Each one of these remarks will require a different opening response from the worker.

(3) Start where the consumer is.

It is important that the worker respond to the consumer's opening remarks. This is often difficult for the inexperienced worker. Concern with helping the consumer, fear of not doing a good job or preoccupation with other matters may cause the worker to hear only part of what the consumer has said. The worker's response which is based on hearing a partial message, may be inappropriate and cut the consumer off from fully explaining his/her need. In responding to the consumer's opening remarks and the feelings which they convey, the worker demonstrates that $s /$ he is interested and is listening. This is an important step in building a positive relationship. 
If the consumer makes a friendly opening remark about the weather or the surroundings, it is appropriate that the worker respond to this. Starting on a conversational level may give the consumer necessary time to feel comfortable with the worker. If the consumer sounds confused or upset, a sincere reassuring statement from the worker expressing interest and willingness to help may be appropriate.

After responding to the opening remarks, it is often helpful if the worker explains what the $I$ and $R$ service does. The consumer may be confused and unclear about the role of the worker. A brief explanation may clear up misunderstandings. In listening to the explanation the consumer also has an opportunity to get a feeling for who the worker is from the way $\mathrm{s} /$ he expresses him/herself.

(4) Allow the consumer to go at his/her own pace. Don't rush the consumer. The consumer will explain why $s /$ he has called in his/her own way. An interview with an older person may go at a slower pace than one with a younger person. ${ }^{6}$ Displaying impatience or interrupting the consumer is not appropriate. The worker, however, may be able to help the consumer who is having difficulty expressing him/herse1f by focusing or summarizing what the consumer is saying. An explanation of this will be made in the following section. Exercises at the end of this chapter will give the worker an opportunity to practice responding to opening remarks. 


\section{INFORMATION GATHERING}

In the interview, the worker must obtain sufficient information from the consumer to understand his/her needs. Gathering information, should be limited to obtaining only the information which is necessary to make an assessment of the consumer's needs and to make a referral if needed. The worker will find that some consumers readily provide all necessary information, while others have difficulty verbalizing their needs and require assistance.

The worker should distinguish between the expressed need of the client and underlying needs which the consumer has difficulty verbalizing. ${ }^{7}$ The consumer, for example, may open with a remark, "I.would like to find out if there are discount utility rates for seniors." This is the expressed need. Underlying this, however, may be a need for additional income. The consumer may have difficulty paying his/her bills and need additional financial support. The worker should, of course, respond to the expressed need. In addition, by using his/her information gathering skills, the worker should attempt to explore the underlying need. The worker should not assume, however, that all consumers have unspoken needs. Through experience, the worker should develop a sensitivity and an ability to pick up and explore these needs.

Before attempting to discuss topics which are difficult for the consumer to talk about, the worker should develop a relationship with the consumer. The consumer will be more open if $\mathrm{s} /$ he has a sense of trust and confidence in the worker. The consumer, of course, may not wish 
to discuss particular topics. This is his/her right. The worker should be reassured however, that if a positive relationship has developed, the consumer may call back if $\mathrm{s} /$ he was unable to verbalize a need in the first interview. 8

Techniques for information gathering are listed in outline form below. ${ }^{9}$

\section{(1) OBSERVING}

\section{a. Verbal}

The worker should be careful not only to listen to what the consumer says but to observe how it is said. The consumer's tone of voice is a clue to how $s /$ he is feeling. Consider the difference between two consumers, one who says in an angry voice, "I am going to move" and one who says this in a cheerful voice. Being sensitive to the tone of voice is a way of understanding the meaning behind the consumer's message.

b. Non-verbal

Observe the consumer's facial and bodily expressions. This is another clue in understanding the consumer's feelings. The worker should also be sensitive to the consumer's physical condition. Successfully linking a person to a community service includes consideration of the person's ability to use the service. Sensitivity to physical limitations will help in understanding the consumer.

(2) LISTENING

In order to understand the consumer, the worker must listen to what $s /$ he has to say. The best way of gathering information is 
to fully listen to the consumer. Here are a few simple rules.

a. Give the consumer full attention.

The worker has a responsibility to control interferences

in the interview situation, as well as personal distractions. Pre-planning for the interview should help to minimize the chances of interruptions from co-workers and other consumers. During an interview, to the extent possible, a co-worker should answer telephones and respond to consumers who may come in for information. The worker should be involved with one consumer at a time.

Personal distractions and concerns are apt to pop up during the interview. For example, the worker might be reminded of a concern at home or have thoughts about other consumers. These distractions are natural, however, the worker should not dwe11 on these concerns during the interview. The worker should be actively aware of giving the consumer his/her full attention.

b. Don't jump to conclusions. Listen to what the consumer has to say before making an assessment. The worker should never assume s/he knows what the consumer is going to say.

c. Listen before you talk. The worker must be careful to respond to the consumer only after hearing what the consumer has to say. If the worker talks without really listening, there is no communication. 
d. Silences may be appropriate.

The worker should not feel that s/he must fill all pauses and silences in the interview with comments. The consumer may use silences to collect his/her thoughts or to assess the situation. Carefully listening to the consumer will provide clues to what silences mean and when comments by the worker are appropriate.

\section{(3) QUESTIONING}

Questioning is limited to obtaining only information which is necessary to understand the consumer's needs in order to provide information and/or a referral. The worker must remember that the consumer has the right to refuse to answer any questions. The worker should not pry or push the consumer for answers. If the consumer seems hesitant about responding to a particular question, the worker should explain why the information is necessary. If the consumer still does not wish to answer, the worker must respect his/her privacy and be gracious about it.

Questions can be placed into two categories, open and closed questions.

a. Closed question.

These will normally elicit a yes/no type of answer. Questions which start with is, does, have, are closed questions. ${ }^{10}$ For example, "Have you seen a doctor lately?" The expected response should be in the form of yes or no. If specific information is needed from the consumer, this is the type of question to use. 
However, if the worker wants to direct the consumer and help him/her to explore needs, closed questions may be very limiting since they call for a particular response.

b. Open Questions

These questions call for an opinion or interpretation. Open questions give the consumer the opportunity of expressing him/ herself. These questions might start with, "Could you tell me a little more about---" or "What do you think about---" The consumer is free to respond to these questions in any way s/he wishes.

The worker should be aware of using these different forms of questions and the types of responses which they call for from the consumer. Consider the difference between saying to the consumer, "Do you want to apply for welfare?" and saying "How do you feel about applying for welfare?" With the first question, the consumer is asked to give a yes/no answer; with the second, the consumer can explain his/her concerns and feelings.

Questioning is a way of getting necessary information and also a way of directing the interview towards achieving its purpose. If the consumer has become distracted and is talking about a nonrelated issue, the worker might consider asking a question in order to focus the interview on the consumer's need. For example, the worker could say, "A while ago you spoke of---, could you tell me more about that?" The worker should use sensitivity in asking 
these questions, so as not to appear rushed or uninterested.

\section{(4) TALKING}

Talking by the $I$ and $R$ worker should serve the purpose of focusing the interview or providing reassurance to the consumer. Discussion of the worker's personal affairs, experiences or opinions is usually not appropriate. The worker might follow the rule, that if $s /$ he is spending more $1 / 3$ of the interview time talking, s/he is probably talking too much. 11

In helping the consumer to explore and clarify needs, the worker might summarize or help the consumer interpret what $s /$ he has said. The worker might say, "It seems to me, that what you are saying is---" After making a statement such as this, the worker must allow the consumer time to reflect and respond. Interpreting or summarizing may be helpful, however, the worker must be careful not to infringe on the consumer's right of self-determination. 


\section{INFORMATION GIVING AND REFERRAL}

Once the $\mathrm{I}$ and $\mathrm{R}$ worker is satisfied that $\mathrm{s} /$ he has an understanding of the consumer's needs, s/he can begin thinking about what information should be provided. The worker will consider providing only information, or information and a referral. A referral would consist of making an appointment for the consumer with a community service. Information giving will be considered first in this section, followed by guidelines for making referrals.

\section{INFORMATION GIVING}

The following is a list of considerations for providing information. ${ }^{12}$

(1) Understand the consumer's needs.

It is important that the worker have an understanding of the consumer's needs before $s /$ he attempts to provide information. Discussing services and prograns without a thorough knowledge of the consumer is not only a waste of time, but it may be detrimental to fully exploring the consumer's needs.

(2) Consider the consumer's right of self-determination. The consumer should be encouraged to make comments and to discuss any information which is given. In providing information, to the extent possible, the worker should present alternative suggestions of programs and services. The consumer must be involved in any decision making. 
(3) Provide factual and accurate information.

The worker should provide accurate information about the community services and avoid giving personal advise. If the worker is uncertain about any information, it is far better to take the time to verify information and make a call back, than to give the wrong information. The worker should not be afraid of admitting s/he doesn't know something but is willing to take the time to find out.

(4) Carefully explain service information.

The worker must take time to explain and verify information. If it is appropriate, the worker should also explain why $s /$ he is providing particular information. Always check to be sure the consumer has heard and understands the information. If the worker is not sure of this, s/he should ask the consumer to repeat it or possibly suggest that the consumer write the information down.

(5) Give the consumer time to respond to information. The consumer may not find the information which has been provided to be adequate or appropriate. If the consumer does not comment, the worker might ask if the information is sufficient. This is another step in insuring that the consumer is linked to an appropriate service.

\section{REFERRALS}

Referrals go a step beyond information giving. With a referral, the 
worker contacts a community service to set up an appointment for the consumer. Individual $\mathrm{I}$ and $\mathrm{R}$ services have their own forms and processes for making referrals. There are, however, some general guidelines for determining when to make a referral.

The worker should consider making a referral if:

a. The consumer is apprehensive or uncertain about contacting a community service. The consumer may lack experience in using social services, be resistant to asking for help, or fearful of the type of treatment s/he will receive.

b. The consumer has physical or emotional limitations which restrict his/her ability to contact a community service.

c. The community service requires or prefers that referrals are made for services. Arrangements with community services that require referrals should be noted in the resource file. 13

The decision to make a referral is based on the assessment made by the worker of the consumer's needs. If the worker is unsure whether or not a referral is appropriate s/he should discuss this with the consumer. The consumer should be involved in deciding if a referral is necessary.

The following can be used as a check list in making referrals.

1. Explain and discuss the $I$ and $R$ services referral process with the consumer.

2. Get the consumer's consent before making a referral.

3. Get al1 necessary information from the consumer for the referral.

4. Ca11 the community service and make the referra1, provide only necessary information.

5. Call the consumer back when arrangements have been made. 
6. Verify the arrangements with the consumer. ${ }^{14}$

7. Make sure the consumer has transportation and will be able to get to an appointment.

8. Follow up after the date of the appointment to be sure the consumer has made connection with the service provider.

Follow up involves calling the consumer and/or the community service after the referral date to inquire if the consumer was linked to the service. This is an important step in the referral process. In cal1ing the consumer, the worker might find that the consumer was given inappropriate or incomplete information. The consumer may have lost the information about the referral or failed to keep the appointment. The consumer may also have kept the appointment but found that the service provider had no record of it or was not able to help the consumer. ${ }^{15}$ The worker has a responsibility to find out why the consumer was not linked to the service. If the consumer needs additional help or information, the worker should attempt to provide this. 
TERMINATING THE INTERVIEW

Norma11y, when the interview comes to an end, both the worker and the consumer are aware that the purpose of the interview has been satisfied and it is time to terminate. However, at any time during the interview, the consumer has a right to terminate the interaction. 16

Before ending the interview, it is important that the consumer knows and feels that $s /$ he can always call back for $I$ and $R$ services. If a positive relationship has been developed, the consumer will probably be aware of this. However, it is good to reinforce this by stating it at the end. This also serves as a way of terminating the interview.

In closing the interview, the worker should also verify any arrangements for future action. If the worker is going to make a referral or check on information, the consumer should be told when $s /$ he can expect to be called back. Summarizing what has been discussed in the interview and reviewing future actions provide a definite closure to the interaction.

The worker should always try to end the interview on a friendly conversational level. Avoid discussion of emotionally laden topics at the end. ${ }^{17}$ The consumer should be left, if possible, with positive feelings about the interview.

If the consumer does not want to terminate the interview, the worker must decide if the conversation is serving the purposes of the interview. 
If it is not, the worker must consider his/her other work responsibilities. If the consumer wishes to talk, the worker might tactfully explain that although $\mathrm{s} /$ he enjoyed talking, s/he has other work responsibilities. Reassure the person that $\mathrm{s} /$ he can call back if $\mathrm{s} / \mathrm{he}$ has additional $I$ and $R$ inquiries. If the consumer appears to have a need to talk because of a particular problem such as social isolation, the worker may wish to consider providing information or a referral about a service which can alleviate this need. The worker should remember, that it is his/her job to link the consumer to needed services, not to provide the service for him/her.

As a courtesy, in ending a telephone interview, the worker should let the consumer hang up first. The consumer should feel that s/he has ended the interview. 
EXERCISES

\section{BEGINNING THE INTERVIEW}

(1) The following are examples of opening remarks made by older consumers telephoning an $I$ and $R$ service. Consider each remark as if you were receiving it from the consumer over the telephone. Write down what your response would be. Then review pages 46-49. Are you starting where the consumer is, and responding to the opening remark?
a. "I need a ride to my doctor's office next week."
b. "I heard about your service on the radio, I was wondering what you could do for me."
c. "Can you tell me how I can get those home delivered meals for old people?"
d. "My sister heard I could call here for help?"
e. "I am so upset about the way I was treated at the store where I bought a leg brace."
f. "Well, Hello, my what a lovely voice you have."

\section{INFORMATION GATHERING}

(2) The following is a list of sample remarks and the corresponding responses. Using the information gathering techniques which were discussed, write comments on why you consider the I and R worker's responses appropriate or inappropriate. (See suggested answers on next page.)

\section{CONSUMER'S REMARKS}

a. "I am concerned I may have to move into a nursing home."

b. "I've never asked for help before, but my savings is getting very low."

(Voice sounds upset.)

\section{WORKER'S RESPONSE}

"I would be happy to give you all the information $I$ have on nursing homes.

"I know it is difficult to ask for help."

(Paused to let consumer explain

further.) 


\section{CONSUMER' $S$ COMMENTS}

c. "I don't want to go to the hospital again."

(Tearful volce)

d. "I would like to know if there is anyone in the community who will stay overnite with an e1der1y person?"

e. "I am going to need help paying my wife's hospital bill."
WORKER'S RESPONSE

"We11 it usually isn't so bad, my mother always likes to watch the color TV."

"There are a few services that may be of assistance, but if you could explain the situation further I can help better."

"Do you want to apply for welfare?"

\section{INFORMATION GIVING}

(3) In the examples below, is the worker's method of providing information correct? Write down Yes or No. (Answers below) What would you have done? Refer to pages 56-57.

a. "I think this is the correct address ---."

b. "Do you have that information, would you like me to repeat it, so you could write it down?"

c. "We11, I think what you need is ---."

d. "I am not sure if we have a service like that in this community, can I check and call you back?"

e. "Just go to this address, they can help you."

$$
\cdot \text { ON } \cdot \partial \quad \mathrm{SHK} \cdot \mathrm{P} \quad \mathrm{ON} \cdot \mathrm{O} \quad \mathrm{SH} X \cdot \mathrm{q} \quad \mathrm{ON} \cdot \mathrm{e}
$$

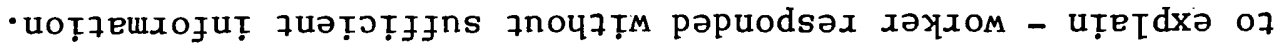

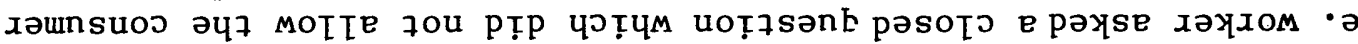

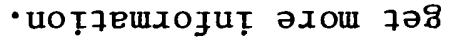

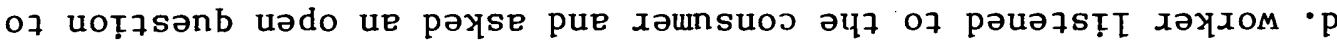

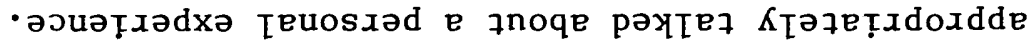

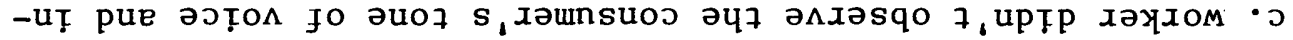

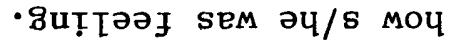

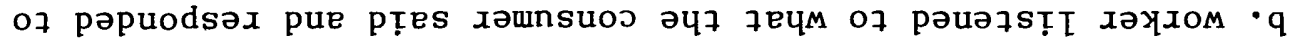

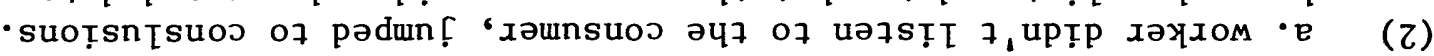


REFERENCES

1 Annette Garrett, Interviewing Its Principles and Methods, 2nd ed., rev. Elinor Zaki and Margaret M. Mangold (New York: Family Service Association of America, 1972), p. 37.

2 Oregon State Program on Aging, "Telephone Techniques", Oregon, 1975. (Mimeographed.)

${ }^{3}$ Alfred Kadushin, The Social Work Interview (New York: Columbia University Press, 1972), p. 139.

${ }^{4}$ Lawrence M. Brammer, The Helping Relationship Process and Skills (New Jersey: Prentice-Hall Inc., 1973), p. 57.

${ }^{5}$ Kadushin, p. 110.

6 Edna Wasser, Creative Approaches in Casework with the Aging

(New York: Family Service Association of America, 1966), p. 34.

${ }^{7}$ Diane C. Tessari et. a1., Information and Referral Services: Information-Giving and Referral 2nd rev. working draft (Washington, D.C.:

Administration on Aging, DHEW), pp. 7-9.

${ }^{8}$ Tessari, p. 8 .

${ }^{9}$ For further discussion of these techniques see Garrett, pp. 36-63.

10 Kadushin, p. 154.

$11_{\text {Ibid, p. } 187 .}$

12 For further discussion of information giving see Tessari et al., pp. 9-14.

${ }^{13}$ Tessari et.al., p. 37.

${ }^{14}$ Ibid pp. $39-40$.

${ }^{15}$ The Assistance Group, Information and Referral Training for State Units on Aging (Maryland: The Assistance Group, 1975), Sec. III p. 87.

${ }^{16}$ Kadushin, p. 208 .

${ }^{17}$ Ibid, p. 212. 


\section{APPENDIX}

SELECTED READINGS

On

Information and Referral

Interviewing

Working with the 0lder Population 


\section{INFORMATION AND REFERRAL}

Cushing, Martha and Long, Nicholas. Information and Referral Services: Reaching Out, rev. ed. Washington, D.C.: Administration on Aging, DHEW, 1974 (DHEW Pub. No. (OHD) 75-20110)*49 pg. Manual.

Defines outreach, provides detailed instructions for community canvasing. Chapt. 4 discusses worker's role and offers suggestions for interviewing.

Forsman, Carolyn. Information and Referral Centers: A Resource Guide Arizona: The Alliance of Information and Referral Services, 1975. reprint ed., American Library Association: Information for the Community. Manfred Kochen and Joseph C. Donohue, eds., 1975. 12 pg. Booklet.

Good annotated bibliography on $I$ and $R$ literature and listing of national and international organizations serving as $I$ and $R$ resources.

For copy write: The Alliance of Information and Referral Services 1515 East Osborn Road Phoenix, Arizona 85014

INTERSTUDY. Information and Referral Services: Notes for Managers, working draft. Washingtion, D.C.: Administration on Aging, DHEW, 1971.* $28 \mathrm{pg}$. Booklet.

Useful considerations for setting up small $I$ and $R$ center for the elderly.

INTERSTUDY. Information and Referral Services: The Role of Advocacy. working draft. Washington D.C.: Administration on Aging, DHEW, 1971. $12 \mathrm{pg}$. Booklet

Well written, practical description of issues involved in I and $R$ advocacy.

Long, Nicholas; Anderson, Jacqueline; Burd, Reginald; Mathis, Mary Elizabeth; Todd, Seldon P. Information and Referral Centers: A Functional Analysis. 3rd ed. Washington, D.C.: Administration on Aging, DHEW, 1974. (DHEW Pub. No. (OHD) 72-20235) 47 pg. Manual.

Good concise overview of the history, functions and purpose of $I$ and $R$ centers. Excellent orientation reading for workers.

*For Administration on Aging and INTERSTUDY publications write: National Clearinghouse on Aging U.S. Dept of Health Education and Welfare D.C., 20201 
Long, Nicholas; Reiner, Steven; Zimmerman, Shirley. Information and Referral Services: The Resource File. Washington D.C.: Administration on Aging, DHEW, 1973. (DHEW Pub. No. (OHD) 75-20111) $15 \mathrm{pg}$. Manual.

Detailed instructions for planning, Developing and utilizing a resource file.

Tessari, Diane C.; Zimmerman, Shirley; Yonce, Leslie J.; Long, Nicholas. Information and Referral Services: Information-Giving and Referral. working draft. 2nd rev. Washington, D.C.: Administration on Aging, DHEW, 1974. (DHEW Pub. No. (OHD) 74-20112) $63 \mathrm{pg}$. Manual.

Presents general principles of $I$ and $R$ service delivery, interviewing techniques and guidelines for information giving and referral.

United Way of America. National Standards Information \& Referral Services. Virginia: United Way of America, 1973. $15 \mathrm{pg}$. Booklet.

Establishes minimum standards and guidelines for $\mathrm{I}$ and $\mathrm{R}$ services. Excellent for use in establishing or evaluating $\mathrm{R}$ service.

For copy write: United Way of America 801 North FairFax St. Alexandria, Virginia 22314 


\section{INTERVIEWING}

Benjamin, Alfred. The Helping Interview Boston: Houghton Mifflin Company, 1969.171 pg. Book.

Useful reference for locating Information on specific interviewing techniques.

Brammer, Lawrence M. The Helping Relationship Process and Skills. New Jersey: Prentice-Ha11, Inc., 1973. 170 pg. Book.

Helpful for increasing one's understanding about the role of a helper and the dimensions of a helping relationship.

Garrett, Annette. Interviewing Its Principles and Methods. 2nd ed., rev. Elinor P. Zaki and Margaret M. Mangold. New York: Family Service Association of America, 1972. 209 pg. Book.

Wel1 written, practice oriented, covers basic interviewing principles.

Kadushin, Alfred. The Social Work Interview. New York: Columbia University Press, 1972. $337 \mathrm{pg}$. Book.

Comprehensive text for indepth study of social work interviewing. 
WORKING WITH THE OLDER POPULATION

Booth, F. Estelle. Reaching Out to the Hard-To-Reach 0lder Person. 3rd ed. San Francisco: San Francisco Senior Center, 1973. $40 \mathrm{pg}$. Booklet.

Useful, encouraging guide on how to locate and motivate isolated older persons. Based on experiences of S.F. Senor Center but applicable to other outreach efforts.

For copy write: San Francisco Senior Center 890 Beach St.

San Francisco, California 94109

Brody, Elaine M. and Brody, Stanley J. "Decade of Decisions for the E1der1y." Social Work 19 (September 1974): 544-54.

Good discussion of the status of the aged and implications for social work.

Butler, Robert N. and Lewis, Myrna I. Aging \& Mental Health: Positive Psychological Approaches. Saint Louis: the C.V. Mosby Company, 1973. 306 pg. Book.

Well written, practical, conveys a realistic picture of elderly in this society. Presents issues on mental health care.

Field, Minna. The Aged, The Family and The Community. New York: Columbia University Press, 1972. 258 pg. Book.

Easy reading, provides overall perspective on the aged and implications for social work practive.

Ford, Caroline S. "Ego-Adaptive Mechanisms of Older Persons." Socia1 Casework 46 (January 1965): 16-21.

Brief discussion on adaptive techniques used by the elderly.

Pincus, Allen. "Reminiscence in Aging and Its Implications for Social Work Practice." Social Work 15 (July 1970) 47-53.

Discusses the importance of reminiscing for the elderly.

Soyer, David, "Reverie on Working with the Aged." Social Casework 50 
(May 1969): 291-294.

Enjoyable reading, personal narrative on the meaning of work with the elderly.

U.S., Department of Health, Education, and Welfare. Public Health Service. Working With 01der Persons: A Guide to Practice, Vo1. III. The Aging Person: Needs and Services. Washington, D.C.: Government Printing Office, 1970. (Public Health Service Pub. No. 1459 - Vol. III July 1970) 90 pg Manual.

Compilation of articles on needs and services of the aged.

Wasser, Edna. Creative Approaches in Casework With the Aging. New York: Family Service Association of America, 1966. 97 pg Book.

Good presentation of issues involved in providing social services to the aged. Discusses developmental tasks of the elderly.

For copy write: Family Service Association of America 44 East 23rd St.

New York, N.Y. 10010 